\title{
Indigenous Fire-Managed Landscapes in Southeast Australia during the Holocene-New Insights from the Furneaux Group Islands, Bass Strait
}

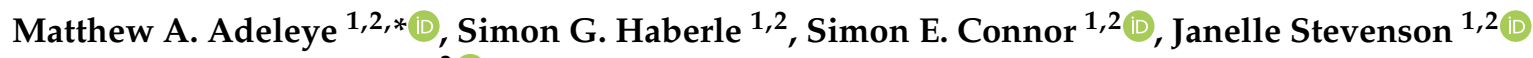 \\ and David M.J.S. Bowman ${ }^{3}$ (D) \\ 1 School of Culture, History and Language, College of Asia and the Pacific, The Australian National University, \\ Canberra 2601, ACT, Australia; simon.haberle@anu.edu.au (S.G.H.); Simon.Connor@anu.edu.au (S.E.C.); \\ janelle.stevenson@anu.edu.au (J.S.) \\ 2 Australian Research Council Centre of Excellence for Australian Biodiversity and Heritage, \\ The Australian National University, Canberra 2601, ACT, Australia \\ 3 School of Natural Sciences, University of Tasmania, Sandy Bay 7001, TAS, Australia; \\ david.bowman@utas.edu.au \\ * Correspondence: matthew.adeleye@anu.edu.au
}

Citation: Adeleye, M.A.; Haberle, S.G.; Connor, S.E.; Stevenson, J.; Bowman, D.M.J.S. Indigenous Fire-Managed Landscapes in Southeast Australia during the Holocene-New Insights from the Furneaux Group Islands, Bass Strait. Fire 2021, 4, 17. https://doi.org/ 10.3390 / fire 4020017

Academic Editors: Chad M. Hoffman and Philip Higuera

Received: 18 December 2020

Accepted: 22 January 2021

Published: 29 March 2021

Publisher's Note: MDPI stays neutral with regard to jurisdictional claims in published maps and institutional affiliations.

Copyright: (c) 2021 by the authors. Licensee MDPI, Basel, Switzerland. This article is an open access article distributed under the terms and conditions of the Creative Commons Attribution (CC BY) license (https:// creativecommons.org/licenses/by/ $4.0 /)$.

\begin{abstract}
Indigenous land use and climate have shaped fire regimes in southeast Australia during the Holocene, although their relative influence remains unclear. The archaeologically attested midHolocene decline in land-use intensity on the Furneaux Group islands (FGI) relative to mainland Tasmanian and SE Australia presents a natural experiment to identify the roles of climate and anthropogenic land use. We reconstruct two key facets of regional fire regimes, biomass (vegetation) burned (BB) and recurrence rate of fire episodes (RRFE), by using total charcoal influx and charcoal peaks in palaeoecological records, respectively. Our results suggest climate-driven biomass accumulation and dryness-controlled BB across southeast Australia during the Holocene. Insights from the FGI suggest people elevated the recurrence rate of fire episodes through frequent cultural burning during the early Holocene and reduction in recurrent Indigenous cultural burning during the mid-late Holocene led to increases in BB. These results provide long-term evidence of the effectiveness of Indigenous cultural burning in reducing biomass burned and may be effective in stabilizing fire regimes in flammable landscapes in the future.
\end{abstract}

Keywords: fire frequency; biomass burned; southeast Australia; Tasmania; Furneaux Group; Holocene; aboriginal cultural burning; Bass Strait

\section{Introduction}

Fire has been part and parcel of the Australian landscape for millions of years, with fireadapted plant species widespread across the continent [1-4]. On a regional scale, moisture variability and vegetation type are the major biogeographic drivers of fire regimes in Australian landscapes [4-7]. Localized factors, such as human activity, topography and herbivory are also key drivers of fire regimes globally [8,9]. Indigenous land use is thought to have shaped the landscape for tens of thousands of years through traditional managed burning practices that create fire mosaics, especially in central and northern Australia [4,10-13].

During the Holocene, Indigenous land use has driven fire regimes sensu lato since at least the last 6000 years [14-20] and ecosystem changes associated with Indigenous fire use is thought to have been greatest in fire-sensitive ecosystems such as temperate rainforests [20]. While efforts have been made to separate the effects of Indigenous fire use from climate as cause of vegetation change (e.g., [21,22]), the regional-scale aspects of fire regimes (amount of biomass burned and recurrence rate of fire) that are influenced by past Indigenous land use remain unclear. Similarly, the role of climate change in past 
fire regimes is not fully understood and confounded by persistent anthropogenic land use during the Holocene [23,24].

Archaeological records from the eastern Bass Strait islands (Furneaux Group) in southeast Australia suggest a reduction in the islands' occupation densities since their separation from the surrounding land masses by mid-Holocene sea-level rise [25]. These islands provide a rare natural laboratory to explore the different roles of climate and anthropogenic land use in past changes in fire regime, given their history contrasts with land-use intensification evident on the mainland at the same time [24,26]. Understanding the individual roles of long-term anthropogenic and climatic drivers in past changes in fire regime in southeast Australia will better inform predictions of fire regime change in the region.

Sedimentary charcoal records in catchments (e.g., peatlands, lakes, swamps) have been empirically proven to reflect vegetation biomass burned within $50 \mathrm{~km}$ source area(s) [27] In particular, total sedimentary charcoal influx has been shown in many cases to reflect amount of vegetation biomass burned regionally [28-33]. Charcoal influx peaks have also been validated empirically as a proxy for recurrence rate of fire episodes above the regional background rate of biomass burned $[29,30,34,35]$. In this study, we use these proxies to decompose Holocene fire regimes of the Furneaux Group Islands (FGI) of southeast Australia into biomass burned (BB) and recurrence-rate-fire-episodes (RRFE). We then compare these two facets of fire regimes of the FGI to independent records of climate and anthropogenic land-use using generalized linear models, to identify the major drivers of change. We also compare these reconstructions to those from surrounding landmasses of southeast mainland Australia and Tasmania to compare the role of Indigenous landuse practices and climatic changes in past changes in fire regime in southeast Australia more generally. Our aim is to identify the roles of climate and anthropogenic land use in the southeast Australian fire regimes during the Holocene, and also draw insights from the FGI, especially regarding the role of anthropogenic land use in modulating biomass burned and the recurrence of rate of fire episodes.

\subsection{Study Region}

\subsubsection{Dominant Climatic Modes in Bass Strait and Southeast Australia}

The southeast Australian climate is influenced by El Niño Southern Oscillation (ENSO), Indian Ocean Dipole (IOD) and the Southern Annular Mode (SAM) ([36-40], Figure 1). ENSO and SAM are the dominant modes in the FGI, Bass Strait and the wider Tasmanian region. ENSO drives rainfall variability in winter, spring and summer. SAM, which is the pattern of Southern Westerly Winds (SWW), drives shifts in rainfall variability between western and eastern southeast Australia [36,39-41]. Variability in wet-dry conditions influences fire occurrence driven by the aforementioned climatic modes, especially ENSO, which governs interannual fire variability across southeast Australia [39,42,43]. Zonal shifts in SWW flow were the dominant climatic mode across southeast Australia during the early to mid-Holocene, while ENSO has prevailed since the mid-Holocene [44]. Recent studies also suggest the IOD has played a significant role in driving catastrophic fires, especially on the southeast mainland since European colonisation [37,45].

\subsubsection{Vegetation}

The natural vegetation of the southeast Australian mainland is characterized by various types of fire-promoted sclerophyllous woodlands/forests and shrublands, as well as large areas of grassland (Figure 1). Western Tasmania, which receives the highest amount of rainfall in the region is characterized by fire-sensitive rainforests and large areas of flammable sedgeland and moorland, while eastern Tasmania, which is in the rain shadow, supports drier sclerophyllous woodlands [46]. The FGI are characterized by coastal scrub and heathlands, with localized sclerophyllous woodlands/forests in some areas (Figure 1 inset) $[47,48]$.

Pollen records suggest Casuarinaceae woodland dominated southeast Australian mainland vegetation during the early Holocene, while Eucalyptus woodland expanded 
in many areas, at least since mid-Holocene, as climate became variable [49]. Rainforest communities expanded in western Tasmania through the early to mid-Holocene and Eucalyptus woodland also expanded in the region, with increasing climate variability since mid-Holocene (e.g., [17-19]). Conversely, Eucalyptus woodland generally expanded in eastern Tasmania throughout the Holocene but was reduced and replaced by coastal heathland and scrub in coastal sites due to the mid-Holocene sea-level transgression (e.g., [50,51]). Similarly, sea-level rise drove the replacement of Eucalyptus woodland by coastal heathland and scrub on the FGI around the same time [52,53].

\subsubsection{Past Human Occupation}

Indigenous occupation was widespread across southeast Australia during the Holocene, but major expansion occurred from the mid to late Holocene on the mainland and Tasmania $[23,24]$. Conversely, widespread human occupation on the Bassian Plain and today's islands, especially the FGI, was concentrated during the early to mid-Holocene and markedly reduced since the mid-Holocene [25]. Bass Strait was previously a plain and a connecting landbridge for human movements between Tasmania and the Australian mainland before its inundation by postglacial sea-level rise between $\sim 14,000$ and 6000 years ago [54-57]. Human occupation (and land use) is thought to have declined on the FGI by $\sim 5000$ years ago, possibly as a result of sea-level encroachment and declining resource availability as the islands shrank $[25,57]$.

Table 1. Site information of charcoal records from the Furneaux Group islands, Bass Strait.

\begin{tabular}{|c|c|c|c|c|}
\hline Site Name & Latitude & Longitude & Elevation (m) & Source \\
\hline Middle Patriarch Lagoon (MPL) & $-39.9963^{\circ}$ & $148.1833^{\circ}$ & 15 & McWethy et al. (2017) \\
\hline Inlet Lagoon (IL) & $-39.7638^{\circ}$ & $147.9594^{\circ}$ & 10 & McWethy et al. (2017) \\
\hline Big Reedy Lagoon (BRL) & $-40.3589^{\circ}$ & $148.238^{\circ}$ & 26 & Adeleye et al. (in press) \\
\hline truwana East Coast Lagoon (tECL) & $-40.33083^{\circ}$ & $148.3611^{\circ}$ & 3 & Adeleye et al. (in press) \\
\hline Green Lagoon (GL) & $-40.442967^{\circ}$ & $148.143840^{\circ}$ & 10 & Adeleye et al. (in press) \\
\hline Crystal Lagoon (CL) & $-40.4774^{\circ}$ & $148.351^{\circ}$ & 8 & Adeleye et al. (in prep.) \\
\hline Apple Orchard Lagoon (AOL) & $-40.325^{\circ}$ & $148.2161^{\circ}$ & 3 & New site \\
\hline Tobacco Lagoon (TL) & $-40.3228^{\circ}$ & $148.3603^{\circ}$ & 20 & New site \\
\hline Piano Point Lagoon (PPL) & $-40.4367^{\circ}$ & $148.0503^{\circ}$ & 10 & New site \\
\hline Bumpy Lagoon (BL) & $-40.4515^{\circ}$ & $148.071^{\circ}$ & 11 & New site \\
\hline
\end{tabular}

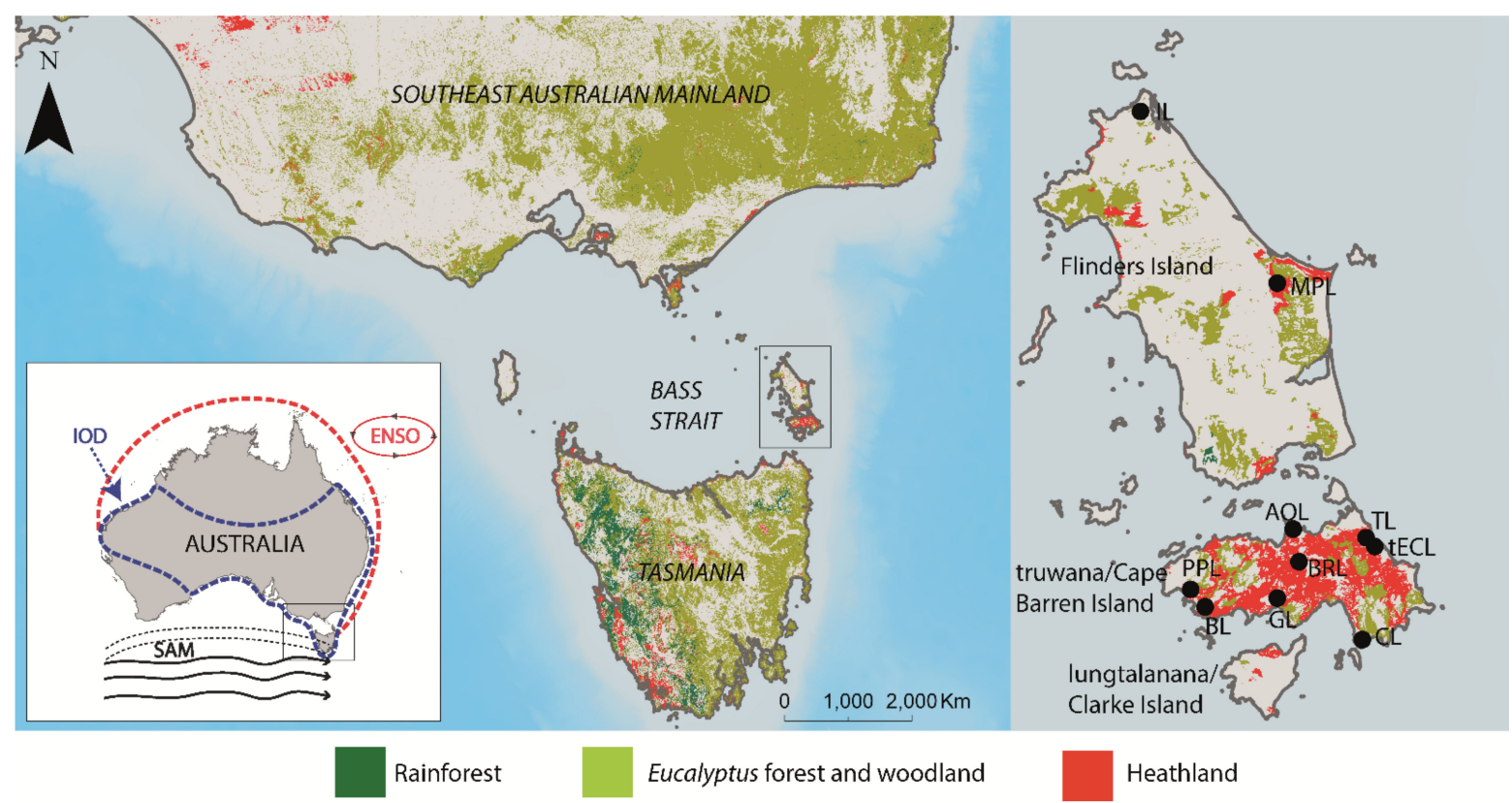

Figure 1. Major climatic modes influencing southeast Australia. A positive Indian Ocean Dipole phase (IOD) generally drives less rainfall, higher temperatures and extreme fire weather in parts of Australia (blue-broken lines) in winter and spring, while rainfall 
is significantly higher in winter and spring during negative IOD phases (Australian Bureau of Meteorology). Southern Annular Mode (SAM) is generally a short-lived oscillation and most pronounced in Tasmania (grey-broken lines). A positive SAM phase features increased summer rainfall (but dry winter) in eastern Tasmania, while a negative SAM phase features increased summer rainfall in western Tasmania and increased winter rainfall in both eastern and western Tasmania [40]. Positive El Niño Southern Oscillation (ENSO) years (La Niña) generally bring higher annual rainfall to many parts of Australia (red-broken lines), while negative years (El Niño) are associated with low annual rainfall and extreme fire weather [40]. Colour-shaded areas represent major vegetation types, which include Eucalyptus forest and woodland (olive), rainforest (green) and heathlands (red). Light grey-shaded area outside southeast Australia region margin represents the continental shelf [58]. Major vegetation communities and sites with charcoal records (black circles) in the Furneaux Group islands, Bass Strait (see Table 1 and Figure 2 for full site names). Vegetation information is adapted from "major vegetation groups"-National Vegetation Information System version 5.1 [59].

\section{Materials and Methods}

\subsection{Composite Charcoal Influx as a Proxy for Vegetation Biomass Burned (BB)}

Composite analysis of multiple records of charcoal influx reflects the amount of vegetation $\mathrm{BB}$ in the landscape on a regional to continental scale, with minimal sedimentation and taphonomy-related biases [30,60,61]. We applied this method, with z-score transformation, to ten high-resolution ( $1 \mathrm{~cm}$ interval) macroscopic charcoal records (charcoal fragments $>125 \mu \mathrm{m}$ in size) from the FGI (Flinders Island and truwana/Cape Barren Island) to estimate regional BB during the Holocene (Figure 2; Table 1). Five out of the 10 sites are published records, while the remaining 5 are newly analysed sites. Charcoal extraction and quantification followed the method of Whitlock and Larsen (2001) [62]. Composite analysis was conducted using the "pfCompositeLF" function (two-way smoothing) in "paleofire" package in " $\mathrm{R}$ " $[33,63]$. All chronologies are published age-depth models and Accelerator Mass Spectrometry AMS dates and age-depth models for newly analysed sites are provided in Table S2 and Figures S2-S5 in Supplementary Materials. Note: BB is a centennial-scale average of regional charcoal production (influx).

\subsection{Charcoal Influx Peak Component as a Proxy for Recurrence-Rate-of-Fire-Episodes (RRFE)}

The use of peak components of charcoal influx is an established proxy for RRFE reconstruction, a decadal frequency of above-average charcoal influx events, and commonly analysed using the "CharAnalysis" program [34,64,65]. We applied this method to reconstruct RRFE for individual sites, with the temporal envelope of peak detection set to 500 years. Charcoal peaks were calculated by setting "cPeak" to residuals, which is the difference between total charcoal accumulation rates and background charcoal. The threshold for peak detection was determined using percentile cut-off of noise distribution with a Gaussian mixed model, and minimum count cut-off probability was set to 0.05 . The resulting peak frequencies for all sites were interpolated to 200-year intervals for consistency with charcoal composites and the average of all sites' peak frequencies taken to represent regional RRFE (number of fire episodes per 500 years) for the FGI. Each fire episode represents one or more major fire events per 500 years. RRFE or charcoal peaks are not taken to reflect fire severity [34]. Developing reliable proxies for palaeofire severity is the goal of current research efforts [66].

The overall results (BB and RRFE) for the FGI were compared to reconstructed palaeofire for the southeast mainland and Tasmania. See Figure S1 and Table S1 in Supplementary Materials for site details for the charcoal records used in reconstructing palaeofire for these regions.

\subsection{Identifying Drivers of Fire Regimes across Southeast Australian Regions Using Generalized Linear Modelling}

Generalized linear modelling (GLM) with Gaussian distribution was applied to identify major drivers of BB and RRFE in the past, with ENSO, SWW-driven effective precipitation and anthropogenic land use as the predictors. The effect of temporal autocorrelation 
was removed from the models by bootstrapping at a lower resolution 1000 times [63]. Best models were selected based on the corrected Akaike's information criterion (AICc). The analysis was done in "R" [67] using the "TSA", "stats" and "EnvStats" packages [68,69]. The Laguna Pallcacocha lake sedimentation record was used as a proxy for ENSO events [70], reconstructed precipitation:evaporation from southwestern Victoria as a proxy for SWWdriven effective precipitation [71] and the number of radiocarbon dates from archaeological evidence of past human occupation as a proxy for anthropogenic land use [23].
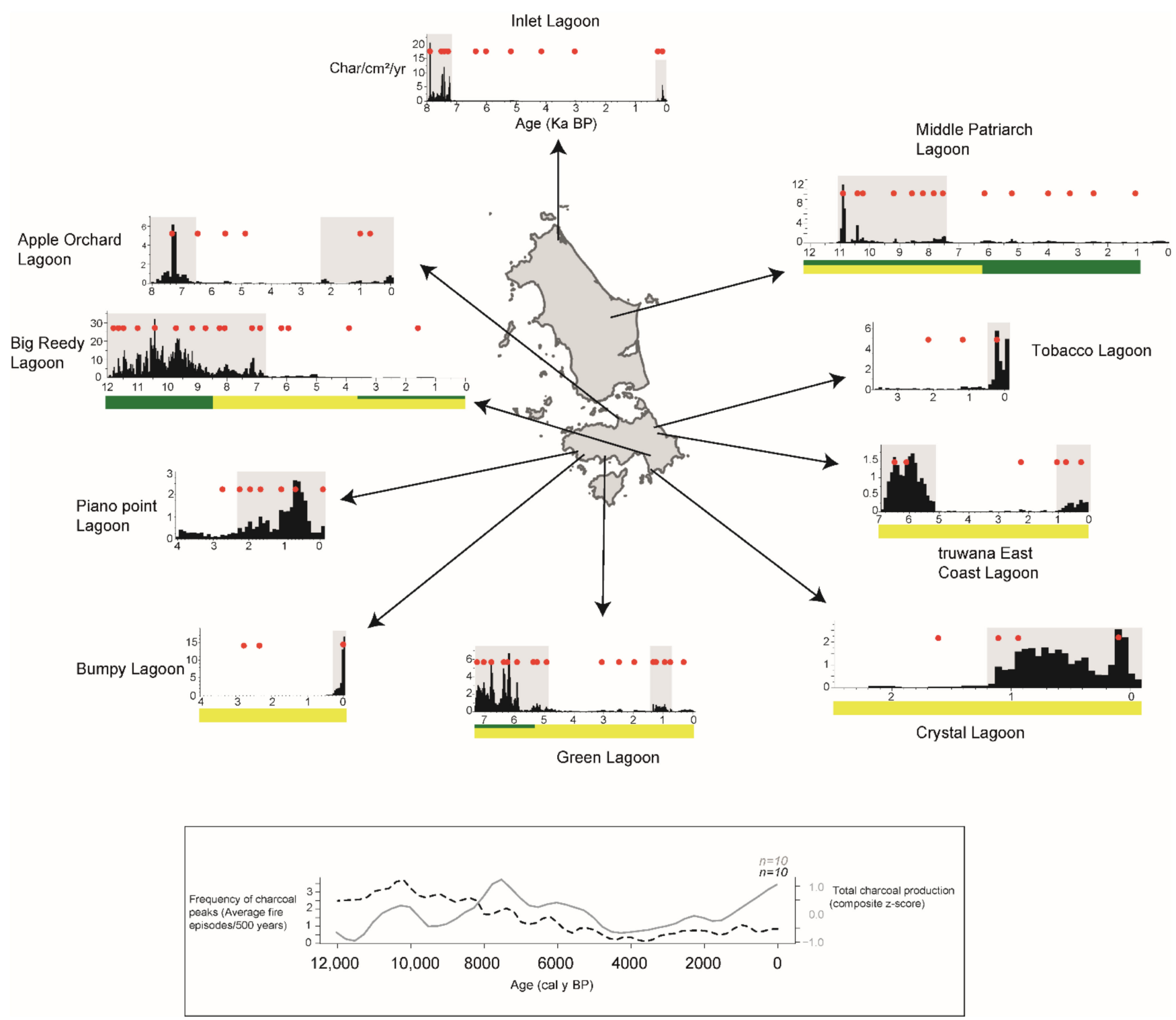

Figure 2. Charcoal accumulation rates with charcoal peaks (red dots) for each site on the Furneaux Group islands, Bass Strait. Periods of major fire activity (high charcoal accumulation) during the early-mid Holocene and late Holocene are shaded in grey. Colour bars represent temporal vegetation types, which include woodland (green) and a combination of heath and scrub (yellow) [52,53,72]. The horizontal axis in each record represents age (calendar years before present, i.e., 1950 AD). The rectangular box shows the composite of all charcoal records'-regional biomass burned (grey curve) and frequency of charcoal peaks-recurrence rates of fire episodes (black dashed curve) for the Furneaux Group. 


\section{Results}

\subsection{FGI Holocene Regional Palaeofire Reconstruction}

Charcoal accumulation rates (CHAR) were high at most sites on the FGI between early and mid-Holocene ( 12,000-6000 cal y BP), with an average CHAR of 2-7 particles $/ \mathrm{cm}^{2} / \mathrm{y}$ and charcoal concentration of 70-300 charcoal particles $/ \mathrm{cm}^{3}$. CHAR was low at most sites in the mid-late Holocene particles $/ \mathrm{cm}^{2} / \mathrm{y}$ and charcoal concentration of $\sim 50$ charcoal particles $/ \mathrm{cm}^{3}$. CHAR and charcoal concentrations increased at most sites in the last 1000 years, reaching an average of 100 particles $/ \mathrm{cm}^{2} / \mathrm{y}$ and 100 charcoal particles $/ \mathrm{cm}^{3}$, respectively (Figure 2; see Figure S6 in Supplementary Materials for average CHAR and charcoal concentration curves). Charcoal peak analysis identified high numbers of significant $(p<0.05)$ peaks across sites in the early-mid Holocene and fewer peaks after this period.

A non-linear relationship was observed between RRFE and BB on the FGI, confirming that total charcoal influx and influx peaks are measures of different aspects of fire regimes on the landscape; in other words, high RRFE is not always associated with high levels of biomass burning (Figure 3). Charcoal composite results show a low-gradual increase $(z$-score $<0)$ in BB on the FGI at the beginning of the Holocene, with a major increase after $\sim 9000$ cal y BP $(z$-score $>0)$. BB later declined $(z$-score $<0)$ from $\sim 5000$ to 2000 cal y BP and increased again ( $z$-score $>0$ ) in the last $\sim 1500$ years (Figure 2$)$. Conversely, RRFE was highest ( $\sim 3$ fire episodes $/ 500$ years) on the FGI during the early Holocene ( 12,000-8000 cal y BP) and consistently declined to $\sim 1$ fire episode/500 years through mid-late Holocene, with a minor increase in the last $\sim 3000$ years (Figure 2). GLM results suggest that a combination of anthropogenic land use, ENSO and SWW-driven effective precipitation-controlled BB on the FGI during the Holocene, while a combination of anthropogenic land use and ENSO drove RRFE (Table 2).

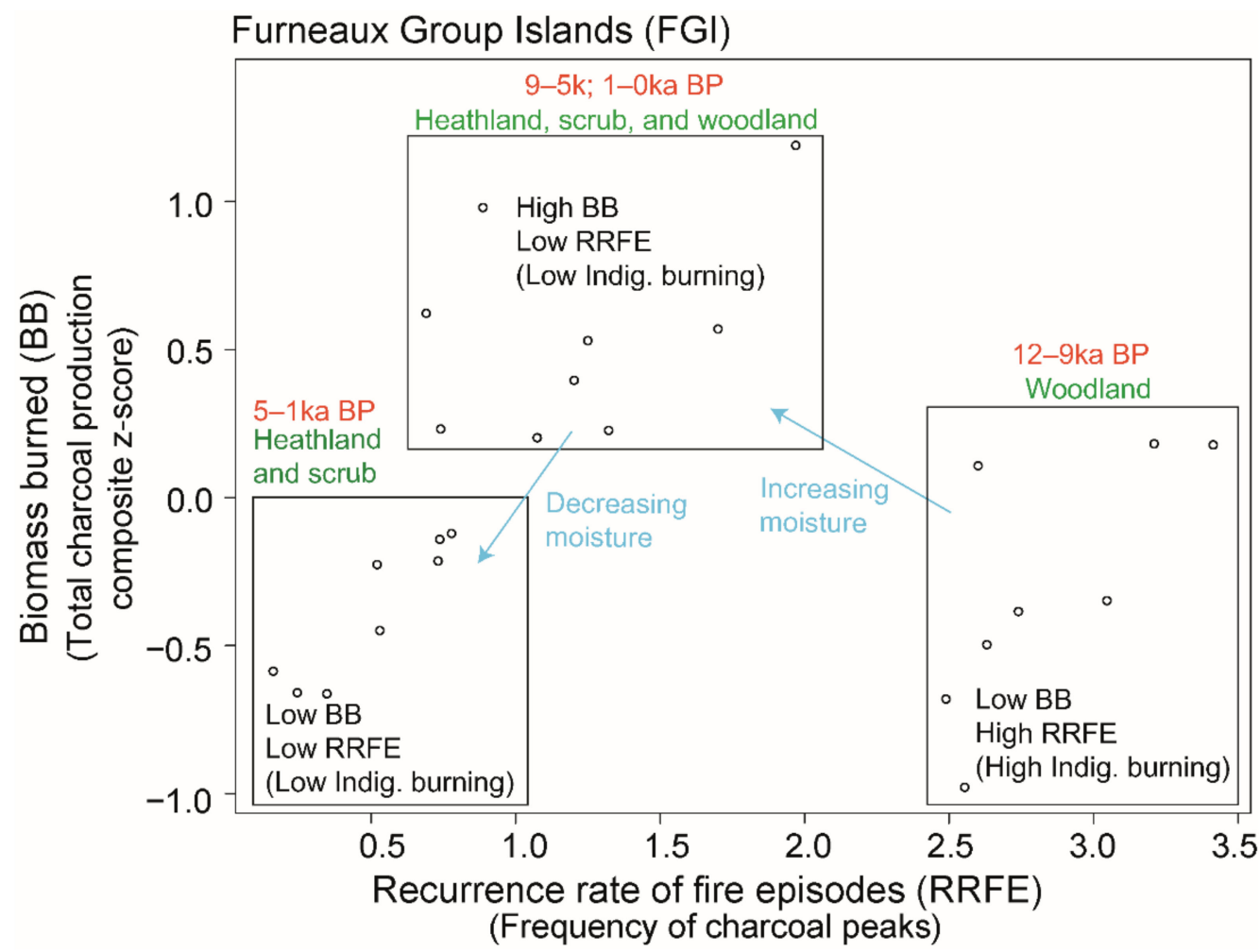

Figure 3. Scatter plot showing a non-linear relationship between RRFE and BB on the FGI during the Holocene in relation to changes in climate and Indigenous (Indig.) land use. Each point represents a 500-year period relationship between BB (total charcoal production) and RRFE (frequency of charcoal peaks). 
Table 2. Generalized linear modelling (GLMs) of biomass burned (BB) and recurrence-rate-of-fire-episodes (RRFE) as a function of ENSO, SWW-driven effective precipitation and anthropogenic land use (human). Models are ranked based on corrected Akaike's information criterion corrected for small sample sizes (AICc), and top models are in bold. Percentage of deviance (\%Dev) explained by models and marginal $\mathrm{R}^{2}(\mathrm{Rm})$ are also shown.

\begin{tabular}{|c|c|c|c|c|c|}
\hline Region & Model & $\mathrm{AICc}$ & dAICc & $\mathbf{R m}$ & $\%$ Dev \\
\hline \multirow[t]{16}{*}{ Furneaux Group } & BB $\sim$ Human + ENSO + Precipitation & 32.79763 & 0 & 62.11 & 66.4 \\
\hline & $\mathrm{BB} \sim \mathrm{Human}+\mathrm{ENSO}$ & 34.32317 & 1.526 & 56.1 & 50 \\
\hline & BB Human + Precipitation & 40.59263 & 7.795 & 49.27 & 62 \\
\hline & BB Precipitation & 51.575 & 18.777 & 26.56 & 46.2 \\
\hline & BB $\sim$ ENSO + Precipitation & 53.88739 & 21.09 & 26.97 & \\
\hline & $\mathrm{BB} \sim$ Human & 56.39019 & 23.593 & 17.6 & \\
\hline & $\mathrm{BB} \sim \mathrm{ENSO}$ & 57.53586 & 24.738 & 15.72 & \\
\hline & Null & 62.03616 & 29.239 & 0 & \\
\hline & RRFE Human + ENSO & 13.20343 & 0 & 93.82 & 95 \\
\hline & RRFE Human + ENSO + Precipitation & 18.09869 & 4.895 & 93.9 & 96 \\
\hline & RRFE Human + Precipitation & 23.2508 & 10.047 & 92.42 & \\
\hline & RRFE Human & 30.02591 & 16.822 & 89.86 & \\
\hline & RRFE ENSO + Precipitation & 84.77862 & 71.575 & 59.28 & \\
\hline & RRFE $\sim$ ENSO & 93.53249 & 80.329 & 49.85 & \\
\hline & RRFE Precipitation & 107.6661 & 94.463 & 19.07 & \\
\hline & Null & 118.7938 & 105.59 & 0 & \\
\hline \multirow[t]{16}{*}{ Southeast mainland } & BB $\sim$ ENSO + Precipitation & -3.69868 & 0 & 32.2 & 47.3 \\
\hline & $\mathrm{BB} \sim \mathrm{ENSO}$ & -3.28083 & 0.418 & 18.89 & 28.5 \\
\hline & BB Precipitation & -2.45098 & 1.248 & 24.93 & 41 \\
\hline & BB Human + Precipitation & -0.73134 & 2.967 & 42.12 & 55 \\
\hline & BB $\sim$ Human + ENSO + Precipitation & -0.16225 & 3.536 & 46.25 & 61.2 \\
\hline & $\mathrm{BB} \sim$ Human + ENSO & -0.03095 & 3.668 & 32.97 & 46.9 \\
\hline & Null & 2.751073 & 6.45 & 0 & \\
\hline & $\mathrm{BB} \sim$ Human & 3.805082 & 7.504 & 19.04 & 47.7 \\
\hline & RRFE $\sim$ Human + ENSO + Precipitation & 44.8662 & 0 & 86.47 & 90.6 \\
\hline & RRFE Human + Precipitation & 49.99191 & 5.126 & 82.94 & 86.4 \\
\hline & RRFE Human + ENSO & 56.78118 & 11.915 & 79.53 & 87.4 \\
\hline & RRFE Human & 67.34123 & 22.475 & 70.55 & \\
\hline & RRFE ENSO + Precipitation & 100.1835 & 55.317 & 36.71 & \\
\hline & RRFE Precipitation & 104.936 & 60.07 & 23.39 & \\
\hline & RRFE $\sim$ ENSO & 105.7968 & 60.931 & 27.53 & \\
\hline & Null & 116.3326 & 71.466 & 0 & \\
\hline \multirow[t]{16}{*}{ Western Tasmania } & BB Human + ENSO + Precipitation & -21.034 & 0 & 81.59 & 83.1 \\
\hline & BB ENSO + Precipitation & -14.9711 & 6.063 & 68.64 & 76 \\
\hline & BB Precipitation & -1.8434 & 19.191 & 52.12 & \\
\hline & BB Human + Precipitation & 3.869802 & 24.904 & 56.2 & \\
\hline & $\mathrm{BB} \sim \mathrm{ENSO}$ & 17.30092 & 38.335 & 14.88 & \\
\hline & Null & 21.40191 & 42.436 & 0 & \\
\hline & $\mathrm{BB} \sim \mathrm{Human}+\mathrm{ENSO}$ & 21.8768 & 42.911 & 18.3 & \\
\hline & BB Human & 23.02665 & 44.061 & 9.16 & \\
\hline & RRFE Human + Precipitation & -2.16589 & 0 & 66.53 & 72.1 \\
\hline & RRFE Human + ENSO + Precipitation & 0.499337 & 2.665 & 66.7 & 78.1 \\
\hline & RRFE Human & 10.23483 & 12.401 & 43.39 & \\
\hline & RRFE ENSO + Precipitation & 11.81571 & 13.982 & 38.75 & 52.7 \\
\hline & RRFE Human + ENSO & 12.7847 & 14.951 & 43.44 & 66.7 \\
\hline & RRFE Precipitation & 15.75663 & 17.923 & 27.43 & 27.7 \\
\hline & RRFE ENSO & 18.15752 & 20.323 & 19.76 & \\
\hline & Null & 24.62277 & 26.789 & 0 & \\
\hline
\end{tabular}

\subsection{FGI Holocene Palaeofire Compared to Other Southeast Australian Regions}

As recorded for the FGI, a generally low-gradual increase in BB was also observed on the mainland at the beginning of the Holocene, with a major increase after $~ 9000$ cal y BP. A similar trend was also observed in eastern Tasmania, which has similar vegetation to 
the mainland; however, $\mathrm{BB}$ reconstruction for the region is considered less robust due to data limitation $(n=2)$ (see Figure S7 in Supplementary Materials for eastern Tasmania BB reconstruction). BB declined markedly on the FGI from 5000-2000 cal y BP (Figure 4) but remained generally high on the mainland (and eastern Tasmania). Conversely, BB was high in western Tasmania at the beginning of the Holocene $(\sim 12,000-9000$ cal y BP), decreasing between $\sim 9000$ and 4000 cal y BP, and increasing again in the last 4000 years.

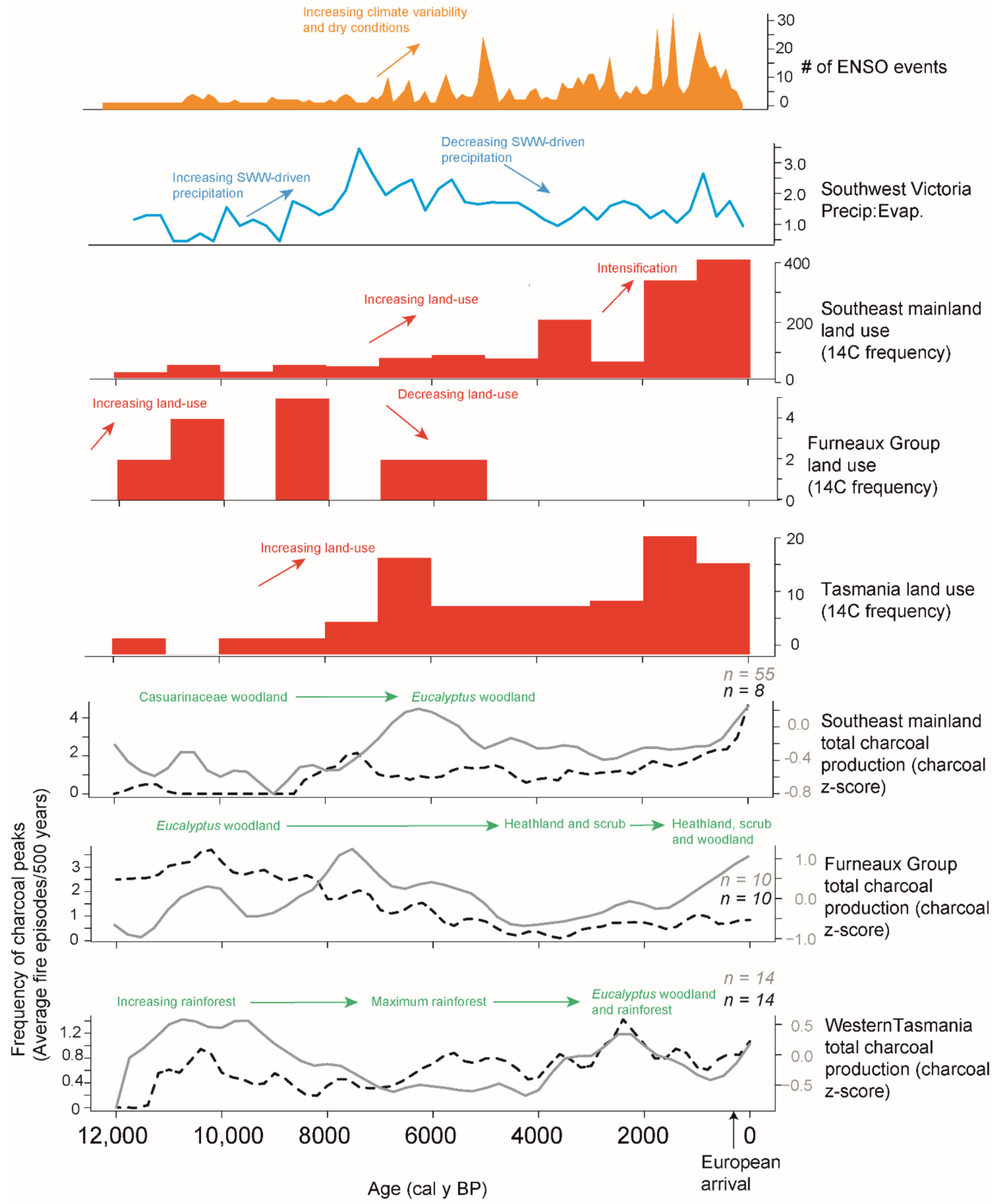

Figure 4. Regional biomass burned-charcoal z-score (solid grey line) and recurrence-rate-of-fire-episodes-average fire episodes/500 years (black dashed line) for the Furneaux Group islands (FGI), western Tasmania and the mainland in relation to vegetation, anthropogenic land use [23], SWW-driven changes in precipitation [67] and ENSO [66]. Vegetation labels are based on major palaeoecological interpretations in published studies from respective regions (e.g., [17-19,49,52,53,72,73]). Note the different scales of $14 \mathrm{C}$ dates (anthropogenic land use). 
High RRFE was recorded for the FGI in the early Holocene ( 12,000-8000 cal y BP) but declined through the rest of the Holocene (Figure 4). RRFE was also relatively high (0.8 fire episodes /500 years) in western Tasmania in the early Holocene ( 12,000-10,000 cal y BP), declined slightly to $\sim 0.4$ fire episodes/500 years between $\sim 10,000$ and 6000 cal y BP and then increased in the last $\sim 6000$ years, reaching up to 1.2 fire episodes/500 years. RRFE shifted from 0.8 to 2 fire episodes $/ 500$ years on the mainland around 8000 cal y BP, with a major increase in the last $\sim 200$ years, reaching $>4$ fire episodes $/ 500$ years (Figure 4 ).

GLM results show SWW-driven effective precipitation and ENSO mainly explain BB across regions, while anthropogenic land use mainly explains RRFE. Anthropogenic land use also contributed to BB in Bass Strait and Tasmania, while ENSO contributed to RRFE in Bass Strait, SWW-driven effective precipitation in Tasmania, and a combination of ENSO and SWW-driven effective precipitation on the mainland (Table 2).

\section{Discussion}

This is the first time that long-term drivers of fire regimes in the Australian landscape have been quantitatively assessed, and our GLM results suggest changes in climate and anthropogenic land use are sufficient to explain fire regimes (regional BB and RRFE) in southeast Australia during the Holocene. Nonetheless, we acknowledge that our results may have incurred potential errors due to limitations associated with some of the proxies used.

\subsection{Potential Sources of Error}

The climatic and anthropogenic proxies considered for our GLMs are currently the best for southeast Australia; however, we acknowledge that the quality of these proxies, especially the use of radiocarbon-dated archaeological evidence of human occupation as an index for regional anthropogenic land use, may have potentially influenced our results. Previous studies have pointed out a number of limitations in the use of radiocarbon-dated archaeological evidence as a proxy for human activity, and biases associated with sampling size, intensity and choice of location have been identified particularly in Australian archaeological records $[57,74-78]$. These factors may have potentially influenced our GLM results. Furthermore, worthy of mentioning is the generally low $\mathrm{Rm}$ and percentage deviation values for $\mathrm{BB}$ on the mainland, which is likely as a result of the quality of charcoal data from the region-mostly non-contiguous microscopic charcoal records, which carry the possibility of missing major fire events (Table 2; Figure S1 in Supplementary Materials). This bias is less problematic in Tasmania and FGI, where contiguously-sampled records prevail.

\subsection{Holocene Drivers of Biomass Burned (BB) in Southeast Australia: SWW-Driven Effective Precipitation and ENSO}

Climate-driven changes in fuel structure and moisture have been widely identified as major drivers of fire regime $[6,79,80]$. However, the operational pattern of these drivers varies in different ecosystems [80,81]. In wet ecosystems with high net primary productivity (rainforests), fuel is generally not a limiting factor, the availability of fuel to burn (dry fuel) is the major limiting factor of fire activity. Conversely, a lack of fuel (low biomass accumulation) generally limits the chances of fire in dry, less productive ecosystems (woodland) [82]. BB in southeast Australia during the Holocene can be explained in the context of climate-driven vegetation growth (biomass accumulation) and changes in biomass moisture. The FGI, mainland and eastern Tasmania generally fall into the category of a less productive dry ecosystem zone, while western Tasmania falls into the category of a wet productive ecosystem zone.

Our GLM results suggest SWW-driven effective precipitation and ENSO were the major drivers of $\mathrm{BB}$ across regions during the Holocene. Though anthropogenic land use contributed significantly to BB in Tasmania and FGI regions, we focus on the major climatic drivers in this discussion (Figure 5). 
BB

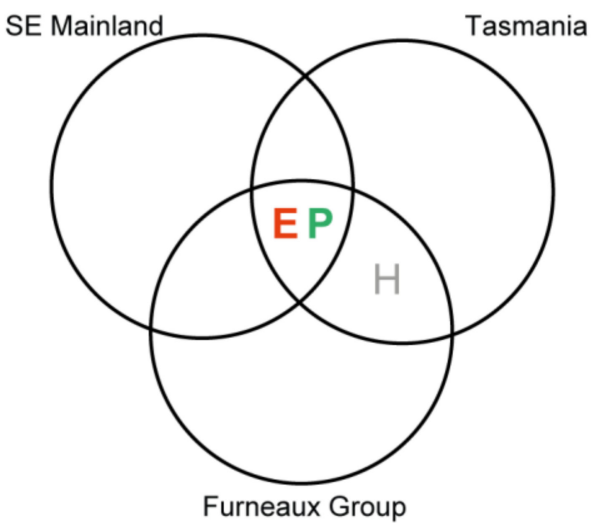

RRFE

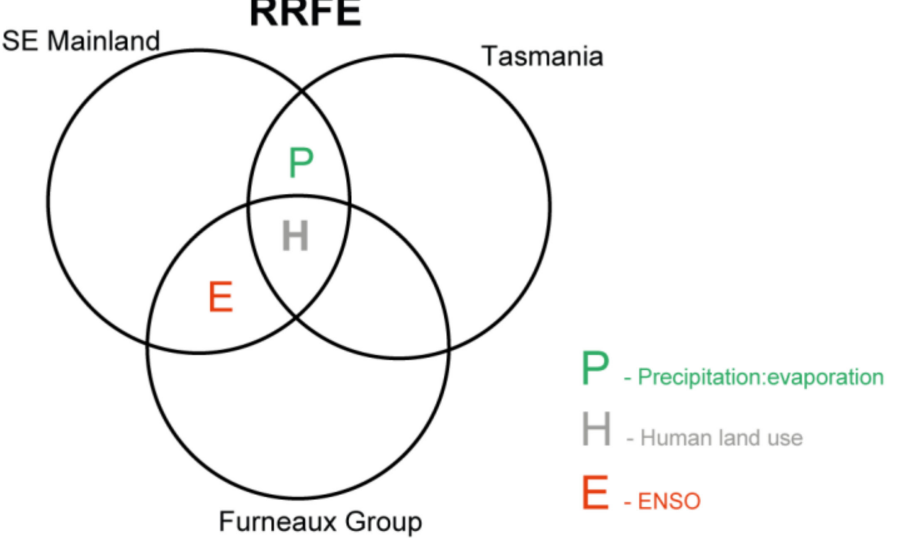

Figure 5. Summary Venn diagrams showing major predictors of Holocene regional biomass burned (BB) and recurrencerate-of-fire-episodes (RRFE) in southeast Australia, based on GLM results in Table 2. Predictors in bold explain biomass burned/fire frequency across all regions.

Southeast Australia is generally thought to have become increasingly wet during the early Holocene, especially between 9000 and 6000 cal y BP $([71,83]$, Figure 4$)$. The generally low BB on the FGI and mainland prior to $\sim 9000$ cal y BP can be associated with reduced biomass accumulation due to low precipitation at this time, and more BB in western Tasmania during this period may be related to biomass dryness and availability to burn (Figure 4). A major increase in BB on the FGI and mainland between 9000 and $6000 \mathrm{cal} y$ BP may be as a result of increased biomass accumulation in woodlands as SWW-driven effective precipitation reached its Holocene maximum. Contrastingly, high precipitation during this period likely increased biomass wetness in western Tasmanian rainforests, with reduced chances of ignitions, leading to a major decline in BB between $\sim 9000$ and 5000 years ago (Figure 4 ).

Alternatively, the heterogenous pattern of BB in southeast Australia between $\sim 12,000$ and $6000 \mathrm{cal}$ y BP (Figure 4) may be as a result of zonal shifts in SWW-driven effective precipitation between eastern and western southeast Australia proposed by Fletcher and Moreno (2012) [44]. These authors suggested stronger SWW-driven effective precipitation in eastern southeast Australia and a weaker SWW flow in western areas between $\sim 12,000$ and 9000 years ago, which may explain reduced BB (wetter fuel) on the FGI and mainland, and more BB (drier fuel) in western Tasmania during this period [84]. This east-west antiphased pattern is thought to have switched between 9000 and 5000 years ago, with less BB in western Tasmania and more BB on the FGI and mainland [44,84]. Additional proxybased studies of Holocene dynamics of SWW-driven effective precipitation are certainly required in southeast Australia, especially in eastern areas (FGI, southeast New South Wales, eastern Victoria, and eastern Tasmania), to fully understand this east-west anti-phased pattern and relationship between $\mathrm{BB}$ and moisture regimes.

SWW-driven effective precipitation weakened in southeast Australia from the midHolocene due to ENSO intensification [44]. Dry conditions associated with ENSO intensification during this period likely promoted drier fuel in western Tasmanian wet forests again, with an increase in BB after $\sim 5000 \mathrm{cal}$ y BP. Drier fuel may have also contributed to more $\mathrm{BB}$ on the mainland during this period. However, the decline in effective precipitation at this time may have reduced biomass accumulation in woodlands on the mainland and FGI, with some decline in BB after $\sim 5000 \mathrm{cal}$ y BP. Although the decline in BB on the mainland was relatively minor, BB declined markedly on the FGI after $\sim 5000$ cal y BP, and this may be as a result of a major decline in woodland vegetation on the FGI at this time $([52,53,72]$, Figures 2 and 4). Sea level-related disturbance (e.g., salt spray, wind damage) is thought to have driven the expansion of sclerophyll shrubby vegetation at the expense of woodland on the FGI during the mid-Holocene, due to higher sea levels and the flooding of the 
continental shelf forming present-day Bass Strait ([53], Figure 2). These vegetation changes may also have reduced fuel loads and connectivity for major biomass burning in the region.

Woodland elements gradually increased again on the FGI in the later part of the Holocene, which is thought to be related to a decline in sea level-related disturbance at this time ([52,53], Figure 2). Increasing vegetation density may have led to the increase in BB (Figure 4). Biomass accumulation at this time may have been slow due to the generally dry conditions; however, when biomass burns it will do so with high intensity when enough biomass accumulates, and this may apply especially in the last 200 years after European colonisation [85].

\subsection{Holocene Drivers of Recurrence Rate of Fire Episodes (RRFE) in Southeast Australia: Anthropogenic Land Use}

Our GLM results show that anthropogenic land use was the primary driver of RRFE across regions (Figure 5), with a secondary role for SWW-driven effective precipitation and ENSO variability.

The high RRFE on the FGI between 12,000 and 9000 cal y BP despite the generally low biomass burned during this period likely reflects recurrent Indigenous fire usage on the FGI (Figure 4, Table 2). Indigenous people likely used frequent fires to maintain open and accessible woodland conditions in order to promote resource availability during this period $[52,53,86]$. The open/mosaic landscapes maintained by Indigenous peoples also corresponded with less biomass burned on the FGI between $\sim 12,000$ and 9000 cal y BP, possibly due to a minimal fuel load and connectivity, decreasing the likelihood of major widespread fire on the landscape. High RRFE associated with Indigenous land use and open woodland is also evident on the mainland and western Tasmania, especially in the last 6000 years (Figure 4 ).

From the mid-Holocene, RRFE on the FGI markedly diverges from that of the surrounding land masses (Figure 4). Recurrent fires associated with Indigenous land use continued on the mainland and western Tasmania in the late Holocene, with intensification in the last $~ 4000-2000$ years, possibly in response to increasing ENSO-driven climate variability and dry conditions. Romano and Fletcher (2018) [21] also found that the primary impact of Indigenous land use in north-western Tasmania in the late Holocene was to stabilize the landscape under more variable climates and minimising vegetation changes. In contrast to increasing RRFE on the mainland and western Tasmania, RRFE declined further on the FGI in the last $~ 5000$ years and overlaps with a reduced human population based on archaeological records [25], which suggests reduced land use. The reduced presence of people as recorded by the archaeology is thought to have been due to postglacial sea-level rise and submergence of the Bassian landbridge [25,55-57] (Figure 4). A reduction in recurrent Indigenous cultural burning practices due to an infrequent use of the islands may have also allowed biomass to accumulate and burn severely on the FGI during the latter part of the Holocene, a pattern that was exacerbated following European colonisation in the last 200 years.

\subsection{Australian Fire Regime and Management}

This study broadly reflects the bioclimatic and anthropogenic control of fire regimes across Australia. Biomass accumulation (vegetation types) and availability to burn (dry biomass), fire weather conditions and anthropogenic activities modulate fire regimes in Australia [6,87]. Long-term dry conditions in particular have been identified to potentially lead to a decline in fire activity in dry woodlands (due to reduced biomass accumulation) and increase fire activity (dry fuel) in temperate forests [6]. A fire behaviour model for southeast Australia [88] also suggests changes in fuel load (biomass accumulation) are the underlying controlling factor of fire behaviour in dry woodlands. These patterns are in line with our results, which show changes in moisture availability (biomass accumulation and dryness) controlled BB in southeast Australian temperate sclerophyll woodlands and temperate rainforests in the past, and these factors will likely continue to shape the fire regime in the region (Figure 6). 


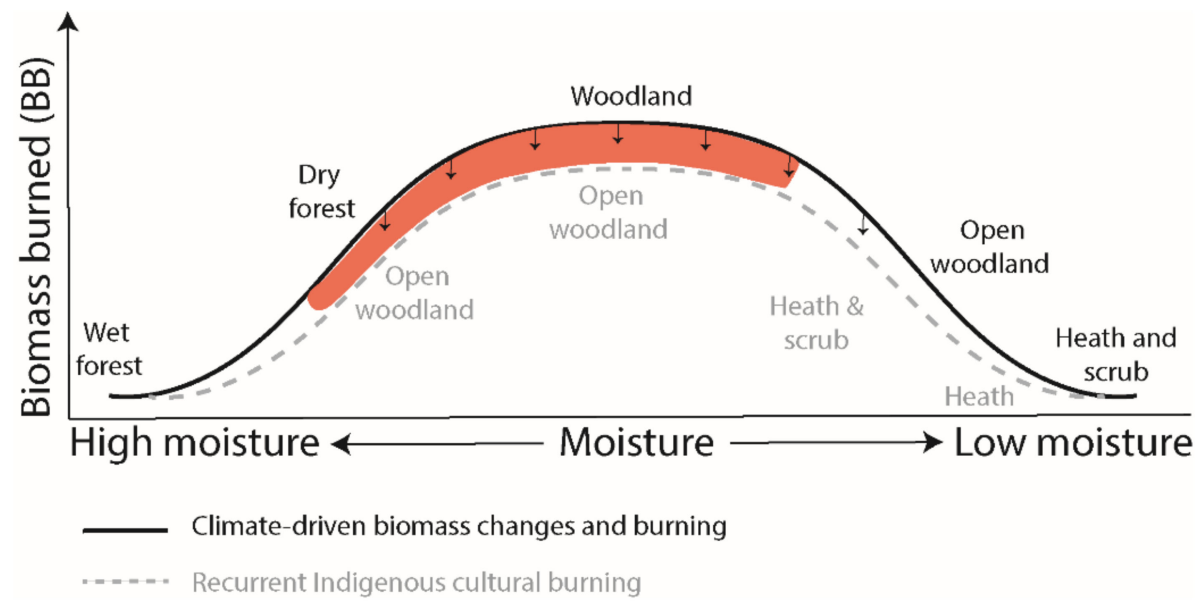

Figure 6. Proposed summary framework (adapted from McWethy et al., 2013) [20] of how climate (black solid line) and recurrent Indigenous cultural burning practices (grey dashed line) modulated fire regimes in southeast Australia during the Holocene. Recurrent Indigenous cultural burning is most important (shaded area) during dry phases in wet forests (drier fuel—dry forest) and during wet phases in woodlands (dense woodland), to reduce biomass accumulation and putting downward pressure on BB. Recurrent Indigenous cultural burning in dry forests and dense woodlands potentially promotes open woodland, with low biomass accumulation and burning. The likelihood of widespread burning in open woodland is low due to reduced fuel connectivity.

Indigenous people have managed the Australian landscape for many millennia, with frequent, low-intensity fire usage to maintain open or mosaic landscapes and promote biodiversity $[10,89,90]$. Apart from increasing resource availability, Indigenous culturallymaintained open/mosaic landscapes also reduced the probability of extensive fires on the landscape, especially in southeast Australia under increasingly dry conditions (ENSO intensification), where catastrophic and widespread fires can easily become the norm rather than the exception [91]. The suppression of Indigenous cultural land management following European colonisation of Australia has resulted in increased biomass accumulation in forest zone, leading to catastrophic fires in recent times [91].

Our results suggest Indigenous land use is mainly reflected in changes in RRFE across regions in the past. Given that fire frequency can shape vegetation structure and composition [92,93], recurrent Indigenous fire-usage likely created open/mosaic diverse vegetation [94], with reduced fuel loads in many parts of southeast Australia during the Holocene. Results for the FGI in particular suggest periods of reduced Indigenous burning allowed biomass accumulation, contributing to an increase in BB on the FGI between $\sim 9000$ and 5000 years ago and the last $\sim 200$ years (Figures 3 and 4). This implies that continued suppression of Indigenous cultural burning practices and other forms of burning such as coordinated hazard reduction, especially in southeast Australian dry forests/woodlands, will result in increasingly widespread large fires on the landscape. This agrees with previous recommendations to reduce fuel loads in these ecosystems to ameliorate fire behaviour induced by warmer and drier climates (fire weather) in the region [88]. Preventing future ecosystem biodiversity and habitat loss associated with catastrophic fires in southeast Australia (e.g., 2019/2020 Black Summer bush fires in southeast Australia) may be facilitated by reinstating an Indigenous cultural landscape management approach.

\section{Conclusions}

Climate-driven biomass accumulation and dryness mainly controlled biomass burned (BB) across southeast Australia during the Holocene. Insights from the Furneaux Group Islands (FGI) suggest recurrent Indigenous cultural burning was mainly associated with less biomass accumulation and burning. This result reflects how Indigenous cultural 
burning worked with the climate to reduce flammable biomass across the landscape in the past. Therefore, reinstating Indigenous cultural burning practices could help reduce the occurrence of catastrophic fire events in southeast Australia's temperate forest ecosystems, thereby minimizing negative impacts on biodiversity, infrastructure and cultural heritage values.

A significant outcome for future research is that the recurrence rates of fire episode (RRFE) estimates are likely a better proxy for anthropogenic burning in sedimentary charcoal records than BB estimates. Considering that high RRFE is not always associated with high levels of biomass burning (as shown on the FGI in the early Holocene), existing Holocene palaeofire records in southeast Australia may primarily reflect a pattern of climate-driven biomass (vegetation) changes rather than Indigenous land use. To avoid potential misinterpretation in future studies, we recommend including both RRFE and BB estimates in future palaeofire studies to better infer anthropogenic land use. In addition to studies of fire severity [66], this will help uncover long-term ecological role of anthropogenic fire and assist in its reinstatement to restore ecological health and Indigenous cultural values to the landscape.

Supplementary Materials: The following are available online at https:/ / www.mdpi.com/2571-625 $5 / 4 / 2 / 17 /$ s1. Details of charcoal records used in reconstructing palaeofire for all regions (Figure S1 and Table S1); AMS dates and age-depth models for newly analysed sites (Table S2 and Figures S2-S5).

Author Contributions: Conceptualization, M.A.A., S.G.H. and S.E.C.; analysis, M.A.A.; writingoriginal draft preparation, M.A.A.; writing—review and editing, S.G.H., S.E.C., J.S. and D.M.J.S.B.; funding acquisition, S.G.H. All authors have read and agreed to the published version of the manuscript.

Funding: This research was funded by Australian Research Council Centre of Excellence for Australian Biodiversity and Heritage, grant number CE170100015. M.A.A. is also supported by an Australian Government Research Training Program (AGRTP) research and international scholarship awards.

Institutional Review Board Statement: Not applicable.

Informed Consent Statement: Not applicable.

Data Availability Statement: The southeast Australian mainland and western Tasmanian charcoal records used in this study can be directly accessed through the Global Paleofire Database (https: //www.paleofire.org/ (accessed on 15 December 2020)), and Furneaux Group Islands charcoal records will be uploaded to the same database upon publication the paper. Charcoal data for eastern Tasmania were obtained from [third party] and are available [from the authors/https://person. zju.edu.cn/en/0018212 (accessed on 15 December 2020); https:/ / www.utas.edu.au/profiles/staff / menzies/penelope-jones (accessed on 15 December 2020)] with the permission of [third party].

Acknowledgments: Additional sediment cores used for this study were collected from the Bass Strait island of truwana/Cape Barren Island with the permission of the Aboriginal Land Council of Tasmania. We would like to thank the truwana Rangers and Pakana Rangers for their hospitality and assistance in the field. The work of the data contributors for southeast Australian mainland through the Global Paleofire Database is gratefully acknowledged. We thank Michela Mariani (University of Nottingham), Feli Hopf (Australian National University), Lynda Mackenzie (Zhejiang University) and Penelope Jones (University of Tasmania) for providing charcoal records for Tasmania, and Dave McWethy (Montana State University) for providing charcoal records for Flinders Island, Bass Strait. We also thank Corey Bradshaw (Flinders University) for generously providing R code for modelling.

Conflicts of Interest: The authors declare no conflict of interest.

\section{References}

1. Crisp, M.; Burrows, G.; Cook, L.; Thornhill, A.H.; Bowman, D.M.J.S. Flammable biomes dominated by eucalypts originated at the Cretaceous-Palaeogene boundary. Nat. Commun. 2011, 2, 193. [CrossRef]

2. Gill, A.M. Fire and the Australian flora: A review. Aust. For. 1975, 38, 1-25. [CrossRef]

3. Beadle, N.C.W. The Vegetation of Australia; Cambridge University Press: Cambridge, UK, 1981. 
4. Miller, B.P.; Murphy, B.P. Fire and Australian Vegetation. In Australian Vegetation, 3rd ed.; Keith, D.A., Ed.; Cambridge University Press: Cambridge, UK, 2017; pp. 113-134.

5. Murphy, B.P.; Bradstock, R.A.; Boer, M.M.; Carter, J.; Cary, G.J.; Cochrane, M.A.; Fensham, R.J.; Russell-Smith, J.; Williamson, G.J.; Bowman, D.M. Fire regimes of Australia: A pyrogeographic model system. J. Biogeogr. 2013, 40, 1048-1058. [CrossRef]

6. Bradstock, R.A. A biogeographic model of fire regimes in Australia: Current and future implications. Glob. Ecol. Biogeogr. 2010, 19, 145-158. [CrossRef]

7. Mooney, S.D.; Harrison, S.P.; Bartlein, P.J.; Daniau, A.L.; Stevenson, J.; Brownlie, K.C.; Buckman, S.; Cupper, M.; Luly, J.; Black, M.; et al. Late Quaternary fire regimes of Australasia. Quat. Sci. Rev. 2011, 30, 28-46. [CrossRef]

8. Whitehair, L.; Fulé, P.Z.; Meador, A.S.; Azpeleta Tarancón, A.; Kim, Y.S. Fire regime on a cultural landscape: Navajo Nation. Ecol. Evol. 2018, 8, 9848-9858. [CrossRef] [PubMed]

9. Archibald, S.; Caroline, E.R.L.; Gómez-Dans, J.L.; Bradstock, R.A. Defining pyromes and global fire regimes. Proc. Natl. Acad. Sci. USA 2013, 110, 6442-6447. [CrossRef]

10. Bowman, D.M.J.S. The impact of Aboriginal landscape burning on the Australian biota. New Phytol. 1998, 140, 385-410. [CrossRef]

11. Gammage, B. Plain facts: Tasmania under aboriginal management. Landsc. Res. 2008, 33, 241-254. [CrossRef]

12. Bird, R.B.; McGuire, C.; Bird, D.W.; Price, M.H.; Zeanah, D.; Nimmo, D.G. Fire mosaics and habitat choice in nomadic foragers. Proc. Natl. Acad. Sci. USA 2020, 117, 12904-12914. [CrossRef]

13. Bowman, D.M.J.S.; Walsh, A.; Prior, L.D. Landscape analysis of Aboriginal fire management in Central Arnhem Land, North Australia. J. Biogeogr. 2004, 31, 207-223. [CrossRef]

14. Black, M.P.; Mooney, S.D. Holocene fire history from the Greater Blue Mountains World Heritage Area, New South Wales, Australia: The climate, humans and fire nexus. Reg. Environ. Chang. 2006, 6, 41-51. [CrossRef]

15. Black, M.P.; Mooney, S.D.; Attenbrow, V. Implications of a 14200-year contiguous fire record for understanding human-climate relationships at Goochs Swamp, New South Wales, Australia. Holocene 2008, 18, 437-447. [CrossRef]

16. Fletcher, M.S.; Wolfe, B.B.; Whitlock, C.; Pompeani, D.P.; Heijnis, H.; Haberle, S.G.; Gadd, P.S.; Bowman, D.M.J.S. The legacy of mid-Holocene fire on a Tasmanian montane landscape. J. Biogeogr. 2013, 41, 476-488. [CrossRef]

17. Fletcher, M.S.; Bowman, D.M.J.S.; Whitlock, C.; Mariani, M.; Stahle, L. The changing role of fire in conifer-dominated temperate rainforest through the last 14,000 years. Quat. Sci. Rev. 2018, 182, 37-47. [CrossRef]

18. Stahle, L.N.; Whitlock, C.; Haberle, S.G. A 17,000-Year-Long Record of Vegetation and Fire from Cradle Mountain National Park, Tasmania. Front. Ecol. Evol. 2016, 4, 82. [CrossRef]

19. Stahle, L.N.; Chin, H.; Haberle, S.; Whitlock, C. Late-glacial and Holocene records of fire and vegetation from Cradle Mountain National Park, Tasmania, Australia. Quat. Sci. Rev. 2017, 177, 57-77. [CrossRef]

20. McWethy, D.B.; Higuera, P.E.; Whitlock, C.; Veblen, T.T.; Bowman, D.M.J.S.; Cary, G.J.; Haberle, S.G.; Keane, R.E.; Maxwell, B.D.; McGlone, M.S.; et al. A conceptual framework for predicting temperate ecosystem sensitivity to human impacts on fire regimes. Glob. Ecol. Biogeogr. 2013, 22, 900-912. [CrossRef]

21. Romano, A.; Fletcher, M.S. Evidence for reduced environmental variability in response to increasing human population growth during the late Holocene in northwest Tasmania, Australia. Quat. Sci. Rev. 2018, 197, 193-208. [CrossRef]

22. Mooney, S.D.; Webb, D.; Attenbrow, V. A comparison of charcoal and archaeological information to address the Influences on Holocene fire activity in the Sydney Basin. Aust. Geogr. 2007, 38, 177-194. [CrossRef]

23. Williams, A.N.; Ulm, S.; Smith, M.; Reid, J. AustArch: A Database of $14 \mathrm{C}$ and Non-14C Ages from Archaeological Sites in Australia-Composition, Compilation and Review (Data Paper). Internet Archaeol. 2014, 36, 1-12. [CrossRef]

24. Lourandos, H. A Late Pleistocene-Holocene Archaeological Sequence from Southwestern Victoria. Archaeol. Ocean. 1983, 18, 81-94. [CrossRef]

25. Sim, R. The Archaeology of Isolation? Prehistoric Occupation in the Furneaux Group of Islands, Bass Strait, Tasmania. Ph.D. Thesis, Australian National University, Canberra, Australia, 1998.

26. Hargrove, W.W.; Pickering, J. Pseudoreplication: A sine qua non for regional ecology. Landsc. Ecol. 1992, 6, 251-258. [CrossRef]

27. Vachula, R.S. A meta-analytical approach to understanding the charcoal source area problem. Palaeogeogr. Palaeoclimatol. Palaeoecol. 2020, 562, 110111. [CrossRef]

28. Duffin, K.I.; Gillson, L.; Willis, K.J. Testing the sensitivity of charcoal as an indicator of fire events in savanna environments: Quantitative predictions of fire proximity, area and intensity. Holocene 2008, 18, 279-291. [CrossRef]

29. Tinner, W.; Conedera, M.; Ammann, B.; Gaggeler, H.W.; Gedye, S.; Jones, R.; Sagesser, B. Pollen and charcoal in lake sediments compared with historically documented forest fires in southern Switzerland since AD 1920. Holocene 1998, 8, 31-42.

30. Ali, A.A.; Blarquez, O.; Girardin, M.P.; Hély, C.; Tinquaut, F.; El Guellab, A.; Valsecchi, V.; Terrier, A.; Bremond, L.; Genries, A.; et al. Control of the multimillennial wildfire size in boreal North America by spring climatic conditions. Proc. Natl. Acad. Sci. USA 2012, 109, 20966-20970. [CrossRef] [PubMed]

31. Carcaillet, C.; Almquist, H.; Asnong, H.; Bradshaw, R.H.W.; Carrión, J.S.; Gaillard, M.J.; Gajewski, K.; Haas, J.N.; Haberle, S.G.; Hadorn, P.; et al. Holocene biomass burning and global dynamics of the carbon cycle. Chemosphere 2002, 49, 845-863. [CrossRef]

32. Carcaillet, C.; Bergman, I.; Delorme, S.; Hornberg, G.; Zackrisson, O. Long-term fire frequency not linked to prehistoric occupations in northern swedish boreal forest. Ecology 2007, 88, 465-477. [CrossRef] 
33. Blarquez, O.; Vannière, B.; Marlon, J.R.; Daniau, A.; Power, M.J.; Brewer, S.; Bartlein, P.J. Paleofire: An R package to analyse sedimentary charcoal records from the Global Charcoal Database to reconstruct past biomass burning. Comput. Geosci. 2014, 72, 255-261. [CrossRef]

34. Higuera, P.E.; Gavin, D.G.; Bartlein, P.J.; Hallett, D.J. Peak detection in sediment-charcoal records: Impacts of alternative data analysis methods on fire-history interpretations. Int. J. Wildland Fire 2010, 19, 996-1014. [CrossRef]

35. Adolf, C.; Wunderle, S.; Colombaroli, D.; Weber, H.; Gobet, E.; Heiri, O.; van Leeuwen, J.F.N.; Bigler, C.; Connor, S.E.; Gałka, M.; et al. The sedimentary and remote-sensing reflection of biomass burning in Europe. Glob. Ecol. Biogeogr. 2018, 27, 199-212.

36. CSIRO. Climate and Water Availability in South-Eastern Australia: A Synthesis of Findings from Phase 2 of the South. Eastern Australian Climate Initiative (SEACI); CSIRO: Canberra, Australia, 2012; p. 41.

37. Abram, N.J.; Wright, N.M.; Ellis, B.; Dixon, B.C.; Wurtzel, J.B.; England, M.H.; Ummenhofer, C.C.; Philibosian, B.; Cahyarini, S.Y.; $\mathrm{Yu}$, T; ; et al. Coupling of Indo-Pacific climate variability over the last millennium. Nature 2020, 579, 385-392. [CrossRef] [PubMed]

38. Fierro, A.O.; Leslie, L.M. Relationships between Southeast Australian Temperature Anomalies and Large-Scale Climate Drivers. J. Clim. 2014, 27, 1395-1412. [CrossRef]

39. Risbey, J.S.; Pook, M.J.; McIntosh, P.C.; Wheeler, M.C.; Hendon, H.H. On the remote drivers of rainfall variability in Australia. Mon. Weather Rev. 2009, 137, 3233-3253. [CrossRef]

40. Australian Bureau of Meteorology. Southern Annular Mode in Australia. Available online: http://www.bom.gov.au/climate/ sam/images/SAM-in-Australia.pdf (accessed on 24 January 2020).

41. Hendon, H.H.; Thompson, D.W.J.; Wheeler, M.C. Australian rainfall and surface temperature variations associated with the Southern Hemisphere Annular Mode. J. Clim. 2007, 20, 2452-2467. [CrossRef]

42. Mariani, M.; Fletcher, M.S.; Holz, A.; Nyman, P. ENSO controls interannual fire activity in southeast Australia. Geophys. Res. Lett. 2016, 43, 10-891. [CrossRef]

43. Mariani, M.; Holz, A.; Veblen, T.T.; Williamson, G.; Fletcher, M.S.; Bowman, D.M.J.S. Climate change amplifications of climate-fire teleconnections in the Southern Hemisphere. Geophys. Res. Lett. 2018, 45, 5071-5081. [CrossRef]

44. Fletcher, M.S.; Moreno, P.I. Have the Southern Westerlies changed in a zonally symmetric manner over the last 14,000 years? A hemisphere-wide take on a controversial problem. Quat. Int. 2012, 253, 32-46. [CrossRef]

45. Williamson, G.J.; Prior, L.D.; Jolly, W.M.; Cochrane, M.A.; Murphy, B.P.; Bowman, D.M. Measurement of inter-and intra-annual variability of landscape fire activity at a continental scale: The Australian case. Environ. Res. Lett. 2016, 11, 035003. [CrossRef]

46. Keith, D.A. Australian Vegetation, 3rd ed.; Cambridge University Press: Cambridge, UK, 2017.

47. Harris, S.; Buchanan, A.; Connolly, A. One Hundred Islands: The Flora of the Outer Furneaux; Tasmanian Department of Primary Industries, Water and Environment: Hobart, Australia, 2001.

48. Harris, S.; Kitchener, A. From Forest to Fjaeldmark. Descriptions of Tasmania's Vegetation; Department of Primary Industries, Water and Environment: Hobart, Australia, 2005.

49. Kershaw, A.P.; D'Costa, D.M.; McEwen Mason, J.R.C.; Wagstaff, B.E. Palynological evidence for Quaternary vegetation and environments of mainland southeastern Australia. Quat. Sci. Rev. 1991, 10, 391-404. [CrossRef]

50. Mackenzie, L.; Moss, P. A late Quaternary record of vegetation and climate change from Hazards Lagoon, eastern Tasmania. Quat. Int. 2017, 432, 58-65. [CrossRef]

51. Jones, P.J.; Thomas, I.; Fletcher, M.-S. Long-term environmental change in eastern Tasmania: Vegetation, climate and fire at Stoney Lagoon. Holocene 2017, 27, 1340-1349. [CrossRef]

52. McWethy, D.B.; Haberle, S.G.; Hopf, F.; Bowman, D.M.J.S. Aboriginal impacts on fire and vegetation on a Tasmanian Island. J. Biogeogr. 2017, 44, 1319-1330. [CrossRef]

53. Adeleye, M.A.; Haberle, S.G.; Harris, S.; Hopf, F.V. Holocene heathland development in temperate oceanic Southern HemisphereKey drivers in a global context. J. Biogeogr. 2021.

54. Cosgrove, R. Late Pleistocene behavioural variation and time trends: The case from Tasmania. Archaeological 1995, 30, 83-104. [CrossRef]

55. Lambeck, K.; Chappell, J. Sea level change through the last Glacial cycle. Science 2001, 292, 679-686. [CrossRef]

56. Sloss, C.R.; Murray-Wallace, C.V.; Jones, B.G. Holocene sea level change on the southeast coast of Australia: A review. Holocene 2007, 17, 999-1014. [CrossRef]

57. Williams, A.N.; Ulm, S.; Sapienza, T.; Lewis, S.; Turney, C.M.S. Sea-level change and demography during the last glacial termination and early Holocene across the Australian continent. Quat. Sci. Rev. 2018, 182, 44-154. [CrossRef]

58. Geoscience Australia. Australian Bathymetry and Topography. 2016. Available online: http://creativecommons.org/licenses/ by/4.0/legalcode (accessed on 24 January 2021).

59. Department of Agriculture, Water and Environment. National Vegetation Information System (NVIS) Version 5.1. Available online: https:/ / www.environment.gov.au/land/native-vegetation/national-vegetation-information-system/data-products (accessed on 18 June 2020).

60. Power, M.J.; Marlon, J.; Ortiz, N.; Bartlein, P.J.; Harrison, S.P.; Mayle, F.E.; Ballouche, A.; Bradshaw, R.H.W.; Carcaillet, C.; Cordova, C.; et al. Changes in fire regimes since the Last Glacial Maximum: An assessment based on a global synthesis and analysis of charcoal data. Clim. Dyn. 2008, 30, 887-907. 
61. Marlon, J.R.; Kelly, R.; Daniau, A.L.; Vannière, B.; Power, M.J.; Bartlein, P.; Higuera, P.; Blarquez, O.; Brewer, S.; Brücher, T.; et al. Reconstructions of biomass burning from sediment-charcoal records to improve data-model comparisons. Biogeosciences 2016, 13, 3225-3244. [CrossRef]

62. Whitlock, C.; Larsen, C. Charcoal as fire proxy. In Tracking Environmental Change Using Lake Sediments: Terrestrial, Algal, and Siliceous Indicators; Smol, J.P., Briks, H.J., Last, W.M., Eds.; Kluwer Academic Publishers: Dordrecht, The Netherlands, 2001.

63. R Core Team. Core. R: A Language and Environment for Statistical Computing (Version 3. 6. 0); R Foundation for Statistical Computing: Vienna, Austria, 2019.

64. Higuera, P.E.; Peters, M.E.; Brubaker, L.B.; Gavin, D.G. Understanding the origin and analysis of sediment charcoal records with a simulation model. Quat. Sci. Rev. 2007, 26, 1790-1809. [CrossRef]

65. Higuera, P.E.; Brubaker, L.B.; Anderson, P.M.; Hu, F.S.; Brown, T.A. Vegetation mediated the impacts of postglacial climate change on fire regimes in the south-central Brooks Range, Alaska. Ecol. Monogr. 2009, 79, 201-219. [CrossRef]

66. Gosling, W.D.; Cornelissen, H.L.; McMichael, C.N.H. Reconstructing past fire temperatures from ancient charcoal material. Palaeogeogr. Palaeoclimatol. Palaeoecol. 2019, 520, 128-137. [CrossRef]

67. Mellin, C.; Bradshaw, C.J.A.; Meekan, M.G.; Caley, M.J. Environmental and spatial predictors of species richness and abundance in coral reef fishes. Glob. Ecol. Biogeogr. 2010, 19, 212-222. [CrossRef]

68. Cryer, J.; Chan, K. Time Series Analysis with Applications in R (Second Edition). 2012. Available online: http:/ /www.stat.uiowa. edu/ \{\}kchan/TSA.htm (accessed on 24 January 2021).

69. Millard, S.P. EnvStats: An R Package for Environmental Statistics; Springer: New York, NY, USA, 2013; Available online: http: //www.springer.com (accessed on 24 January 2021).

70. Moy, C.M.; Seltzer, G.O.; Seltzer, D.T.; Anderson, D.M. Variability of El Niño/Southern Oscillation activity at millennial time scales during the Holocene epoch. Nature 2002, 420, 162-165. [CrossRef]

71. Wilkins, D.; Gouramanis, C.; De Deckker, P.; Fifield, L.K.; Olley, J. Holocene lake-level fluctuations in Lakes Keilambete and Gnotuk, southwestern Victoria, Australia. Holocene 2013, 23, 784-795.

72. Ladd, P.G.; Orchiston, D.W.; Joyce, E.B. Holocene vegetation history of Flinders Island. New Phytol. 1992, 122, 757-767. [CrossRef]

73. Hopf, F.V.L.; Colhoun, E.A.; Barton, C.E. Late-glacial and Holocene record of vegetation and climate from Cynthia Bay, Lake St Clair, Tasmania. Quat. Sci. 2000, 15, 725-732. [CrossRef]

74. Timpson, A.; Colledge, S.; Crema, E.; Edinborough, K.; Kerig, T.; Manning, K.; Thomas, M.G.; Shennan, S. Reconstructing regional population fluctuations in the European Neolithic using radiocarbon dates: A new case-study using an improved method. J. Archaeol. Sci. 2014, 52, e549-e557. [CrossRef]

75. Crema, E.R.; Habu, J.; Kobayashi, K.; Madella, M. Summed probability distribution of 14C dates suggests regional divergences in the population dynamics of the Jomon period in eastern Japan. PLoS ONE 2016, 11, e0154809. [CrossRef] [PubMed]

76. Williams, A.N. The use of summed radiocarbon probability distributions in archaeology: A review of methods. J. Archaeol. Sci. 2012, 39, e578-e589. [CrossRef]

77. Williams, A.N.; Ulm, S.; Turney, C.S.M.; Rodhe, D.; White, G. The establishment of complex society in prehistoric Australia: Demographic and mobility changes in the late Holocene. PLoS ONE 2015, 10, e0128661.

78. Williams, A.N.; Veth, P.M.; Steffen, W.; Ulm, S.; Turney, C.S.M.; Reeves, J.; Phipps, S.; Smith, M. A continental narrative: Human settlement patterns and Australian climate change over the last 35,000 years. Quat. Sci. Rev. 2015, 123, e91-e112. [CrossRef]

79. Cochrane, M.A. Tropical Fire Ecology: Climate Change, Land Use and Ecosystem Dynamics; Praxis Publishing Ltd.: Chichester, UK, 2009.

80. Pausas, J.G.; Paula, S. Fuel shapes the fire-climate relationship: Evidence from Mediterranean ecosystems. Glob. Ecol. Biogeogr. 2012, 21, 1074-1082. [CrossRef]

81. Pausas, J.G.; Bradstock, R.A. Fire persistence traits of plants along a productivity and disturbance gradient in Mediterranean shrublands of south-east Australia. Glob. Ecol. Biogeogr. 2007, 16, 330-340. [CrossRef]

82. Krawchuk, M.A.; Moritz, M.A. Constraints on global fire activity vary across a resource gradient. Ecology 2011, 92, 121-132. [CrossRef] [PubMed]

83. Moros, M.; De Deckker, P.; Jansen, E.; Perner, K.; Telford, R.J. Holocene climate variability in the Southern Ocean recorded in a deep-sea sediment core off South Australia. Quat. Sci. Rev. 2009, 28, 1932-1940. [CrossRef]

84. Mariani, M.; Fletcher, M.S. Long-term climate dynamics in the extra-tropics of the South Pacific revealed from sedimentary charcoal analysis. Quat. Sci. Rev. 2017, 173, 181-192. [CrossRef]

85. Nicholson, Á.; Prior, L.D.; Perry, G.L.; Bowman, D.M. High post-fire mortality of resprouting woody plants in Tasmanian Mediterranean-type vegetation. Int. J. Wildland Fire 2017, 26, 532-537.

86. Gott, B. Aboriginal fire management in south-eastern Australia: Aims and frequency. J. Biogeogr. 2005, 32, 1203-1208. [CrossRef]

87. Russell-Smith, J.; Yates, C.P.; Whitehead, P.J.; Smith, R.; Craig, R.; Allan, G.E.; Thackway, R.; Frakes, I.; Cridland, S.; Meyer, M.C.P.; et al. Bushfires 'down under': Patterns and implications of contemporary Australian landscape burning. Int. J. Wildland Fire 2007, 16, 361-377. [CrossRef]

88. Matthews, S.; Sullivan, A.L.; Watson, P.; Williams, R.J. Climate change, fuel and fire behaviour in a eucalypt forest. Glob. Chang. Biol. 2012, 18, 3212-3223. [CrossRef]

89. Trauernicht, C.; Brook, B.W.; Murphy, B.P.; Williamson, G.J.; Bowman, D.M.J.S. Local and global pyrogeographic evidence that indigenous fire management creates pyrodiversity. Ecol. Evol. 2015, 5, 1908-1918. [CrossRef] [PubMed] 
90. Ens, E.; Walsh, F.; Clarke, P. Aboriginal people and Australia's vegetation: Past and current interactions. In Australian Vegetation; Keith, D.A., Ed.; Cambridge University Press: Cambridge, UK, 2017; pp. 89-112.

91. Fletcher, M.S.; Hall, T.; Alexandra, A.N. The loss of an indigenous constructed landscape following British invasion of Australia: An insight into the deep human imprint on the Australian landscape. Ambio 2021, 50, 138-149. [CrossRef]

92. Rowe, J.S. Concept of fire effects on plant individuals and species. In The Role of Fire in Northern Circumpolar Ecosystems; Wein, R.W., MacLean, D.A., Eds.; John Wiley and Sons: New York, NY, USA, 1983.

93. Noble, I.R.; Slayter, R.O. Concepts and models of succession in vascular plant communities subject to recurring fires. In Fire and the Australian Biota; Gill, A.M., Groves, R.H., Noble, I.R., Eds.; Australian Academy of Science: Canberra, Australia, 1981.

94. Adeleye, M.A.; Mariani, M.; Connor, S.; Haberle, S.G.; Herbert, A.; Hopf, F.; Stevenson, J. Long-term drivers of vegetation turnover in Southern Hemisphere temperate ecosystems. Glob. Ecol. Biogeogr. 1981. [CrossRef] 